й виразу, з власним характером поступу й метою.

\section{ЛІТЕРАТУРА}

1. Витвицький В. Музичними шляхами: Спогади. Мюнхен: Бібліотека Прологу i Сучасности, 1989. Ч. 183.216с.

2. Витвицький В., Колесса М., Лисько 3. під заг. ред. В. Витвицького. Диригентський порадник. Львів: Український видавничий інститут, $1938.240 \mathrm{c}$.

3. Зубеляк М. Витвицький - музикознавець. За океаном: зб. статей. Львів, 1996. С. 3-8.

4. Лехник Л. В. Витвицький - митець і вчений. Музикознавчі праці. Публіцистика. Львів, 2003. C. $8-18$.

5. Михальчишин Я. В. 3 музикою крізь життя. Львів, 1992. С. 211-214.

\section{REFERENCES}

1. Vytvytskyi, V. (1989). Muzychnymy shliakhamy: Spohady [Musical ways: Memories]. Miunkhen, part. 183, p. 216. [in Ukrainian].

2. Vytvytskyi, V., Kolessa, M. \& Lysko, Z. (1938). Dyrygentskyi poradnyk [Conducting advisor]. Lviv, p. 240. [in Ukrainian].

3. Zubeliak, M. (1996). Vytvytskyi muzykoznavets [Vytvytskiy - musicologist]. Overseas: Coll. articles. Lviv, pp. 3-8. [in Ukrainian].

4. Lekhnyk, L. (2003). V. Vytvytskyi - mytets i vchenyi [Vytvytskiy is an artist and scientist]. Musicological works. Journalism. Lviv, pp. 8-18. [in Ukrainian].

5. Mykhalchyshyn, Ya. (1992). Z muzykoiu kriz zhyttia [With music through life]. Lviv, pp. 211-214. [in Ukrainian].

Стаття надійшла до редакції 16.08.2021

УДК 378.011.3-051

DOI:

Марія Ярушак, кандидат педагогічних наук, доцент кафедри загальної педагогіки та дочкільної освіти Дрогобицького державного педагогічного університету імені Івана Франка

\title{
ЗАСТОСУВАННЯ КОМПЕТЕНТНІСНОГО ПІДХОДУ У ПРОЦЕСІ ПІДГОТОВКИ ФАХІВЦІВ ЗАКЛАДІВ ВИЩОЇ ОСВІТИ
}

У статті окреслено особливості реалізації компетентнісного підходу в умовах підготовки фахівців закладів вищої освіти. Представлено аналіз термінологічної єдності дослідників щооо сутнісних характеристик поняття “компетентнісний підхід”, як вплив на особистісні якості та утворення, яка при достатній мотивації забезпечує прочес самореалізації, самозбереження і самовдосконалення особистості студента в процесі професійної діяльності. Окреслено особливості застосування компетентнісного підходу крізь призму практичного досвіду.

Встановлено, щзо реалізація компетентнісного підходу можлива, якщз зміст, методи і організаційні форми навчання, а також діяльність студентів будуть значимі, тобто навчальний процес матиме професійноособистісну спрямованість.

Ключові слова: заклади вищої освіти; компетентнісний підхід; навчання; професійна підготовка; фахіви̧і.

Jim. 12.

Maria Yarushak, Ph.D.(Pedagogy), Associate Professor of the General Pedagogy and Preschool Education Department of Drohobych Ivan Franko State Pedagogical University

\section{APPLICATION OF COMPETENCE APPROACH IN THE PROCESS OF TRAINING PROFESSIONALS OF HIGHER EDUCATION INSTITUTIONS}

The article deals with the peculiarities of the implementation of the competence approach in the conditions of training specialists of higher education institutions. An analysis of the terminological unity of researchers on the essential characteristics of the concept of "competence approach" as an impact on personal qualities and education, which with sufficient motivation provides a process of self-realization, self-preservation and self-improvement of the student's personality in the process of professional activity. Peculiarities of application of the competence approach through the prism of practical experience have been outlined.

It is established that the implementation of the competence approach is possible if the content, methods and organizational forms of learning, as well as the activities of students are significant, the learning process will have 


\section{ЗАСТОСУВАННЯ КОМПЕТЕНТНІСНОГОПДХОДУ У ПРОЦЕСІПІДОТОВКИ ФАХІВЦІВ ЗАКЛАДІВ ВИЩОЇ ОСВІТИ}

a professional and personal orientation. The formation of professional competence in a higher educational institution is a purposeful formation of future professionals, which occurs as a result of the influence of the environment and the process of education on the internal forces of development.

It is proved that for effective formation of professional competence of future specialists in a higher education institution is necessary to apply methods of creative personality development: basics of brainstorming, elements of creative discussion, synectics. We believe that it is effective to use the method of associative models of mental activity, which is based on metaphor, which determines the transfer of a problem or problem to another material.

We also consider effective in the process of forming the competence to use problem-based learning methods through the formulation and solution of non-standard situations, solving complex situations through the use of logic in the search for answers. The following methods are especially effective for the development of different types of competencies: application of the application method, combination method, definition method, critique and update method, recoding and display method (through graphic and schematic representation of phenomena).

Keywords: institutions of higher education; competence approach; education; training; specialists.

П остановка проблеми. Сучасні реалї суспільства регламентують нам застосування компетентнісноорієнтованого підходу, який став новим концептуальним орієнтиром та здатний забезпечувати поступову переорієнтацію системи освіти на створення умов задля оволодіння певними компетенціями. Зазначимо, що поняття "компетентність" також використовується у вітчизняних державних документах. Проблематика розвитку та формування у майбутніх фахівців вищої освіти професійної компетентності є стержнем державної освітньої політики і відображено у документах основної офіційної законодавчонормативної бази України. Йдеться про Національну стратегію розвитку освіти в Україні на період до 2021 р., Державну програму "Вчитель”, Програму “Освіта (Україна ХХІ ст.)”, Закони України "Про освіту”, “Про вищу освіту”, "Про загальну середню освіту" тощо [8].

Аналіз останніх досліджень і публікацій. Сутність професійної компетентності викладача окреслено у працях О. Грисюк [1], А. Зельницького [2], А. Комишана [3], І. Ярмола [11]. Організаційнопедагогічні умови розвитку професійної компетентності педагога окреслено у працях С. Мартиненко [5], І. Сологор [7], А. Хоменко [9].

Аналіз наукової літератури виявив посилену увагу дослідників до проблеми формування професійної компетентності у майбутніх викладачів закладів вищої освіти. Слід зазначити, що сутність цього поняття дослідники аналізують з позицї науково-компетентнісного підходу.

Мета статті полягає у науковому обгрунтуванні особливостей застосування компетентнісного підходу у процесі підготовки фахівців закладів вищої освіти.

Виклад основного матеріалу дослідження. Досліджуване нами поняття "компетентність" у сучасних умовах $\epsilon$ предметом посиленого дослідження у сфері різноманітних дисциплін. Концепція компетентності є стержнем розвитку навчальних програм та рушійною сила процесу змін. Вона визначається як "розвиток складних здібностей, які дозволяють студентам мислити та діяти у різних сферах діяльності" [3, 575].

Зокрема, у сфері педагогічної науки цю категорію асоціюють 3 компетентнісною моделлю В. Клафкі. Дослідник розробив ії у рамках критично-конструктивної дидактики. Згідно з його трактуванням, компетентність слід розуміти як вміння й навички врегулювати різні ситуації у полі відповідних галузей, що спричиняє готовність діяти певним чином $[4,129]$. Дослідник поєднав фактично-категоріальні, методичні та вольові елементи у межах опису компетентності.

Інша позиція задекларована у працях психолога Ф. Вайнерта. Він визначав компетентність як "когнітивні здібності та навички, необхідні людям задля вирішення конкретних проблем, а також пов'язані з ними мотиваційні, вольові й соціальні навички та вміння успішно й відповідально діяти в різних ситуаціях" $[10,4]$.

Зокрема, формування професійної компетентності умайбутнього фахівця під час практичного навчання взаємопов'язана із системою впровадження освітніх проектів, що включає: інтеграцію особистого, професійного, фінансового, технічні та освітні ресурси, інноваційну підготовку компетентних фахівців у конкретному середовищі; адаптацію наукових проєктів до специфіки процесу навчання. Крім того, створюється необхідне соціальнесередовище,якестимулюссамовдосконалення, саморозвиток та особистісну реалізацію. У цьому контексті професія вимагає компетентності. 3 цієі причини професійна сфера працюе 3 компетенціями, формуванням знань, умінь та навичок.

Водночас інтеграція майбутнього фахівця у професійну діяльність залежить від його особистих якостей, професійної компетентності, досвіду. Майбутні фахівці мають знати, як складати індивідуальну освітню програму для учнів, встановлювати міжпредметні та циклічні зв'язки між дисциплінами; для проєктування організації освітнього процесу; визначати найбільше раціональні освітні форми, методи та технології. 


\section{ЗАСТОСУВАННЯ КОМПЕТЕНТНІСНОГОПІДХОДУ У ПРОЦЕСІ ПДГОТОВКИ ФАХІВЦІВ ЗАКЛАДІВ ВИЩОЇ ОСВІТИ}

Розробка та впровадження педагогічної системи формування професійної компетентності студентів у професійному навчанні повинно здійснюватися $з$ урахуванням умов, включаючи цільові, діяльнісні, інформативні й ефективні компоненти.

Європейський парламент та Рада СС у процесі представлення своїх рекомендацій $[11,117]$ акцентували увагу на необхідність розробки системи Базових компетенцій як складової навчання протягом життя. У документі окремо вісім Базових компетенцій: спілкування рідною мовою; володіння іноземними мовами; базові знання математики та загальні знання у науковій сфері; навички роботи з цифровими носіями; навчання для можливості здобуття знань; розвиток i формування соціальних та громадянських навичок; формування навичок ініціативності та практичності.

Британський дослідник М. Армстронг виокремив поведінкові (“м'які”) компетентності. Цей вид компетентностей спрямований на досягнення високого рівня ефективності, здобуття хороших результатів (розвиток емоційного інтелекту, комунікації, набуття стійкості до змін, активності, командної роботи, вміння приймати рішення, здобуття орієнтації на досягнення).

Загалом у науковій літературі йдеться про зростання значення компетентностей у системі вищої освіти. Вони також важливі при розробці відповідних стандартів. У цьому контексті дослідниця С. Мартиненко а виокремлює визначення професійної компетентності як “провідної якісної характеристики” особистості $[4,130]$.

Науковець І. Зязюн досліджує “компетентність” як певну оцінну категорію, яка може характеризувати людину як суб'єкт діяльності, зокрема регламентує здатність успішно виконувати свої повноваження. Компетентність $€$ особливим типом організації знань, а це забезпечує можливість прийняття ефективних, стратегічних рішень $[10,4]$.

Формування професійної компетентності мабутнього фахівця є складним утворенням 3 професійними знаннями як логічної інформації про навколишній й внутрішній світ людини, яка пролонговано фіксується у ії свідомості. Саме тому знання, уміння й навички є діяльнісними характеристиками професійної компетентності, що представлені у стандартах вищої освіти. Цікавим у цьому контексті виступає аналіз професійної компетентності В. Чорнобай, яка розглядає іiі як якісну характеристику ступеня володіння фахівцями професійною діяльністю 3 одночасним регулюванням власного професійного становлення, самовдосконалення та самовиховання $[9,410]$. Отже, структура професійної компетентності складається 3 трьох загальних компонентів: змістового наповнення, мотиваційної сфери та процесу виконання.

Основною метою закладів вищої освіти $є$ набуття навичок студентів, розвиток професійних компетенцій є важливим, але, з іншого боку, відомо, що професіонали, які відчувають себе компетентними, мають більшу внутрішню мотивацію у своїй роботі.

Щодо визначення терміна “компетентність”, то його загалом розуміють як поєднання знань, умінь та індивідуальних характеристик, таких як мотивація, самосвідомість, риси особистості, ставлення, переконання, цінності та інтереси, які можна оцінити і які можуть бути визначальними для відмінностей у продуктивності. Навчання компетентності пов'язане з типом ефективних дій, орієнтованих на подолання проблем та поліпшення соціального контексту, застосування знань та ефективність у використанні ресурсів, завжди 3 точки зору самовідповідальності.

Тобто, в освітньому процесі студентам слід створити умови для розвитку професійної компетентності, застосовуючи елементи компетентнісного підходу:

- оволодіння основами предметних та методичних дисциплін навчального плану зі спеціальності, зокрема, основ педагогіки, психології, інформатики, природознавства, математики;

- забезпечення суб'єкта навчання переходу від засвоєння знань до здатності застосовувати їх у практичній діяльності;

- розвиток самостійності студентів у процесі засвоєння змісту всіх дисциплін у межах навчального плану;

- розвиток різних якостей (мотиваційної активності, відповідальності).

На нашу думку, формування компетентності майбутніх педагогів у закладі вищої освіти виступає як цілеспрямоване становлення майбутніх фахівців, воно може проходити через вплив середовища та підвалин виховання на внутрішні сили розвитку певної особистості, яке проходить в умовах закладу вищої освіти у результаті спільної навчальної діяльності.

У сфері педагогічного процесу на етапі педагогічного проєктування необхідно застосовувати такі форми: розклади, графіки контролю, графіки встановлення міжпредметних зв'язків, вимоги до навчального предмету (уроків), тематичний план [2].

Щодо вищої школи, то необхідно застосовувати 


\section{ЗАСТОСУВАННЯ КОМПЕТЕНТНІСНОГОПДХОДУ У ПРОЦЕСІ ПІДГОТОВКИ ФАХІВЦІВ ЗАКЛАДІВ ВИЩОЇ ОСВІТИ}

нормативні документи: навчальні плани зі спеціальностей, графіки навчального процесу у межах факультету, графік контролю навчальної роботи студентів, розклади занять.

Методичне забезпечення включає створення інструментарію проєктування, до якого І. Тригуб відноситъ “виготовлення схем, зразків документів, поурочні та тематичні папки, в яких викладач накопичує різноманітний матеріал з окремої теми для навчальної групи" $[7,38]$.

У межах освітнього процесу студенти повинні опанувати ці важливі складові професійної компетентності (інформаційно-комунікаційну, комунікативну, когнітивну, креативну, методичну, педагогічну, предметну, соціальну, науководослідну). Це формування має відбуватися на високому рівні для того, щоб мати у майбутній професійній діяльності різні розв'язувати завдання, серед них дослідницького (планування та організація дослідницької роботи), чи практичного змісту (спрямовані на отримання конкретного результату) або завдання педагогічного циклу (уміння спілкуватися у колективі) [6;8].

Для забезпечення ефективності процесу формування професійної компетентності майбутніх фахівців у межах закладу вищої освіти слід використовувати методи розвитку творчості, тобто елементи мозкового штурму, творчої дискусії, синектики, способу організації колективної мислительної діяльності. Зазначаємо, що фективним буде використання методу асоціативних моделей розумової діяльності, який грунтуєтъся на метафоричності $[1,203]$.

Уважаємо за доцільне зазначити, що у процесі формування професійної компетентності студентів закладів вищої освіти необхідно використати весь арсенал наявних способів активізації резервних можливостей студента використання ділових ігор, які наближають навчання до професійної діяльності, сприяють розвитку особистості як майбутнього фахівця [4, 129].

Зіставляючи ділові ігри з традиційними формами проведення занять, робимо висновок, шо вони більш доцільні:

- за допомогою ділової гри можливе досягнення вищого рівня спілкування, ніж при традиційному навчанні, саме тому ділова гра надає можливість реалізувати конкретну діяльність;

- ділові ігри є колективною діяльністю, яка уособлює активну участь всій групі загалом і кожному їі учаснику;

- виконання різних творчих завдань може дати хороший результат, у студентів виникає мотивація виконувати нові завдання;
- проведення ділових ігор надає змогу налагодити контакт, правильного сприймати та оцінювати гру; виробити стратегії і тактики спілкування, при цьому вибрати найбільш відповідні форми і засоби $[5,110]$.

Отже, у процесі проєктування формування професійної компетентності майбутніх фахівців у закладі вищої освіти доцільно впроваджувати використання ділових ігор. Це дає змогу створити оптимальні умови для розвитку мислення, уможливити оволодіння і передавання майбутнім фахівцям культурних норм та правил професійної діяльності.

Висновки. Аналіз психолого-педагогічної літератури за темою дослідження виявив представленістъ наукових розробок щодо застосування компетентнісного підходу щодо процесу формування професійної компетентності майбутніх фахівців. Встановлено, шо у педагогічній науці термінологічна єдність поняття “професійна компетентність”, визначає його як інтегративну якість, наукові знання, особистісні якості для самовдосконалення особистості в процесі професійної діяльності.

В основу педагогічного проєктування процесу формування та застосування компетентнісного підходу необхідно покласти концептуальну модель через формування усвідомлення значущості обраної професії, розвиток психологічної мотиваційної системи оволодіння спеціальністю, спонукання до безперервного професійного самовдосконалення. Доведено, шо ефективними методами формування професійної компетентності майбутніх педагогів у закладі вищої освіти є інтерактивні методи, зокрема ділова гра.

Перспективним напрямом подальших наукових досліджень $є$ аналіз особливостей діяльності приватних та державних закладів освіти медичного і правового профілю у контекті проєктування системи формування професійної компетентності майбутніх фахівців.

\section{ЛІТЕРАТУРА}

1. Грисюк О. Професійна компетентність сучасного педагога у світлі ідей К. Д. Ушинського. Вісник Чернігівського національного педагогічного університету. Педагогічні науки. 2013. Вип. 110. С. 202-204.

2. Зельницький А. Професійна компетентність викладача вищого військового навчального закладу. Військова освіта. 2013. № 2. С. 84-95.

3. Комишан А. I. Професійна компетентність та підвищення кваліфікації педагогів вищої школи: взаємозв'язок й обумовленість. Педагогіка формування творчої особистості в вищій й загальноосвітній школах. 2013. Вип. 33. С. 574-581. 


\section{ЗАСТОСУВАННЯ КОМПЕТЕНТНІСНОГОПДХОДУ У ПРОЦЕСІ ПЦДГОТОВКИ ФАХІВЦІВ ЗАКЛАДІВ ВИЩОЇ ОСВІТИ}

4. Мартиненко С. А. Професійна компетентність, складова професіоналізму особистості: психологопедагогічний аспект. Проблеми сучасної педагогічної освіти. Педагогіка й психологія. 2013. Вип. 40(2). C. $128-132$.

5. Монашненко А. М. Професійна компетентність майбутнього перекладача та її складові. Вісник Вінницького політехнічного інституту. 2014. № 4. C. $110-113$.

6. Сологор I. Професійна компетентність передумова ефективної діяльності викладача іноземної мови. Імідж сучасного педагога. 2014. № 2. С. 16-18.

7. Тригуб I.I. Професійна компетентність експертів в галузі освіти. Педагогічна освіта: теорія й практика. Психологія. Педагогіка. 2015. № 24. С. 38-42.

8. Хоменко А. В. Професійна компетентність вчителя у контексті духовно-моральної парадигми виховання Г. Ващенка. Витоки педагогічної майстерності. Серія : Педагогічні науки. 2009. Вип. 6. С. 16-23.

9. Чорнобай В. Г. Професійна компетентність та пп складові. Науковий вісник Національного університету біоресурсів й природокористування України. Серія: Педагогіка, психологія, філософія. 2014. Вип. 199(1). С. 409-413.

10. Ягупов В. В., Свистун В. І. Компетентнісний підхід до підготовки фахівців в системі вищої освіти. Наукові записки НаУКМА. Серія "Педагогічні, психологічні науки та соиіальна робота”. Т. 71. 2007. С. 3-8.

11. Ярмола І. К. Компетенція та компетентність викладача вищої школи складові його інноваційного розвитку. Запорожский медицинский журнал. 2013. № 5. C. 116-118.

\section{REFERENCES}

1. Hrysiuk, O. (2013). Profesiina kompetentnist suchasnoho pedahoha u svitli idei K. D. Ushynskoho [Professional competence of a modern teacher in the light of the ideas of K. D. Ushinsky]. Bulletin of Chernihiv National Pedagogical University. Pedagogical sciences. No. 110. pp. 202-204. [in Ukrainian].

2. Zelnytskyi, A. (2013). Profesiina kompetentnist vykladacha vyshchoho viiskovoho navchalnoho zakladu [Professional competence of a teacher of a higher military educational institution]. Military education. No. 2. pp. 84-95. [in Ukrainian].

3. Komyshan, A. (2013). Profesiina kompetentnist ta pidvyshchennia kvalifikatsii pedahohiv vyshchoi shkoly: vzaiemozviazok y obumovlenist [Professional competence and professional development of teachers of higher school: the relationship and conditionality]. Pedagogy of creative personality formation in higher and general education schools. Issue 33. pp. 574-581. [in Ukrainian].

4. Martynenko, S. (2013). Profesiina kompetentnist, skladova profesionalizmu osobystosti: psykholohopedahohichnyi aspekt [Professional competence, component of professionalism of the individual: psychological and pedagogical aspect]. Problems of modern pedagogical education. Pedagogy and psychology. Vol. 40(2). pp. 128-132. [in Ukrainian].

5. Monashnenko, A. (2014). Profesiina kompetentnist maibutnoho perekladacha ta yii skladovi [Professional competence of the future translator and its components]. Bulletin of Vinnytsia Polytechnic Institute. No. 4. pp. 110 113. [in Ukrainian].

6. Solohor, I. (2014). Profesiina kompetentnist peredumova efektyvnoi diialnosti vykladacha inozemnoi movy [Professional competence is a prerequisite for effective activity of a foreign language teacher]. The image of a modern teacher. No. 2. pp. 16-18. [in Ukrainian].

7. Tryhub, I. (2015). Profesiina kompetentnist ekspertiv $\mathrm{v}$ haluzi osvity [Professional competence of experts in the field of education]. Pedagogical education: theory and practice. Psychology. Pedagogy. No. 24. pp. 38-42. [in Ukrainian].

8. Khomenko, A. (2009). Profesiina kompetentnist vchytelia u konteksti dukhovno-moralnoi paradyhmy vykhovannia H. Vashchenka [Professional competence of a teacher in the context of the spiritual and moral paradigm of education of G. Vashchenko]. The origins of pedagogical skills. Series: Pedagogical sciences. Vol. 6. pp. 16-23. [in Ukrainian].

9. Chornobai, V. (2014). Profesiina kompetentnist ta пп skladovi [Professional competence and components]. Scientific Bulletin of the National University of Life and Environmental Sciences of Ukraine. Series: Pedagogy, psychology, philosophy. Issue 199(1). pp. 409-413. [in Ukrainian].

10. Iahupov, V. \& Svystun, V. (2007). Kompetentnisnyi pidkhid do pidhotovky fakhivtsiv v systemi vyshchoi osvity [Competence approach to training in higher education]. Scientific notes of NaUKMA. Series "Pedagogical, psychological sciences and social work". Vol. 71. pp. 3-8. [in Ukrainian].

11. Iarmola, I. (2013). Kompetentsiia ta kompetentnist vykladacha vyshchoi shkoly skladovi yoho innovatsiinoho rozvytku [Competence and competence of a high school teacher components of its innovative development]. Zaporozhia medical journal. No. 5. pp. 116-118. [in Ukrainian].

Стаття надійшла до редакції 18.08.2021

\section{OS808NC2}

"Навчання й досі розуміють лише якрозвитокрозуму, в той час коли воно має стати джерелом сил для оновлення та творення".

$$
\begin{array}{r}
\text { Mарія Монтессорі } \\
\text { італійсьқий педагог, лікар, білософб }
\end{array}
$$

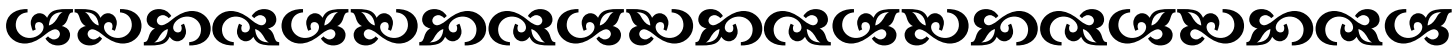

